\title{
Revealed Comparative Advantages and Exports Competitiveness of ASEAN-5 Countries in the Global Market
}

\author{
Muhammad Shahid Maqbool ${ }^{a}$, Furrukh Bashir ${ }^{b}$, Hafeez-ur-Rehman ${ }^{\mathrm{c}}$, Rashid Ahmad ${ }^{\mathrm{d}}$ \\ ${ }^{a}$ Department of Economics, Government Graduate College Gojra, Pakistan \\ Email: shahidmakbool@gmail.com \\ ${ }^{\mathrm{b}}$ Assistant Professor, School of Economics, Bahauddin Zakariya University, Multan, Pakistan \\ Email: furrukh@bzu.edu.pk \\ c Professor/ Chairman, Department of Economics, University of Management and Technology, Lahore, \\ Pakistan \\ Email: hafeez.rehman@umt.edu.pk \\ ${ }^{\mathrm{d}}$ Assistant Professor, School of Economics, Bahauddin Zakariya University, Multan, Pakistan \\ Email: rashid.ahmad@bzu.edu.pk
}

\begin{tabular}{|c|c|}
\hline ARTICLE DETAILS & \multirow{11}{*}{$\begin{array}{l}\text { ABSis study aims at measuring the comparative advantage and } \\
\text { competitiveness of the ASEAN-5 (Malaysia, Indonesia, Philippines, } \\
\text { Singapore and Thailand) economies in the world market. The current } \\
\text { study employed four indices of Revealed Comparative Advantage namely } \\
\text { Revealed Comparative Advantage index (RCA), LnRCA, Vollrath index } \\
\text { (RCA\#) and Revealed Symmetric Comparative Advantage index (RSCA). } \\
\text { The data for the analysis has been taken from International trade center } \\
\text { UN-COMTRADE statistics for the exports of electrical machinery for } \\
\text { these selected economies from 20o3-2O2o. The findings of the analysis } \\
\text { portray that Malaysia, Philippines, Singapore and Thailand had a } \\
\text { comparative and competitive advantage, while Indonesia had a } \\
\text { comparative and competitive disadvantage in the electrical machinery in } \\
\text { the global economy. This study will be helpful for the policy makers to } \\
\text { boost human capital formation and to increase technology transfer and } \\
\text { innovation to enhance the competitiveness and comparative advantage. }\end{array}$} \\
\hline History: & \\
\hline Accepted 28 May 2021 & \\
\hline Available Online June 2021 & \\
\hline Keywor & \\
\hline rative Advantage, & \\
\hline Competitiveness, ASEAN, & \\
\hline Electrical Machinery & \\
\hline JEL Classification: & \\
\hline N1O, L94 & \\
\hline DOI: 10.4706 & \\
\hline
\end{tabular}

(C) 2021 The authors. Published by SPCRD Global Publishing. This is an open access article under the Creative Commons Attribution-

NonCommercial 4.0

Corresponding author's email address: furrukh@bzu.edu.pk

\section{Introduction}

Exports are considered the engine of economic growth that is indispensable for the prosperity and welfare of the nation. An economy can win friends through trade relations among different economies in the world and ensure the optimal allocation of the available resources in the economy. Following the concept of comparative advantage depending on their factor endowments, each economy is likely exporting those products which can be produced at relatively low cost. The ASEAN-5 ( 


\section{Review of Economics and Development Studies, Vol. 7 (2) 2021, 267-276}

Malaysia, Indonesia, Singapore, Philippines and Thailand) exports have been rapidly growing over the last few decades. A large share of high-technology products in ASEAN-5 exports is also an indication that $t$ fear of terms of trade deterioration is not warranted for the ASEAN-5 countries, as their exports are of high quality and consequently of higher price (Ghani and Sofyan, 2014). Electrical and electronic machinery and appliances are the major component of manufactured exports accounting about half of the exports in Malaysia.

Table 1 Export growth product group 85 of ASEAN-5 economies in the world market during 20032020

\begin{tabular}{|r|r|r|r|r|r|}
\hline Years & \multicolumn{1}{|l|}{ Malaysia } & \multicolumn{1}{l|}{ Indonesia } & \multicolumn{1}{l|}{ Philippines } & \multicolumn{1}{l|}{ Thailand } \\
\hline 2004 & 11.672 & 7.383 & 10.442 & 28.236 & 17.993 \\
\hline 2005 & 9.0549 & 11.5 & -0.676 & 11.773 & 2.2067 \\
\hline 2006 & 3.7199 & -0.51 & 10.029 & 21.093 & 12.492 \\
\hline 2007 & 3.1989 & 4.18 & -0.163 & 3.8453 & 10.942 \\
\hline 2008 & -1.325 & 8.816 & -6.14 & 0.1198 & -0.192 \\
\hline 2009 & -11.23 & -1.42 & -25.24 & -18.92 & -13.09 \\
\hline 2010 & 23.431 & 27.31 & -8.677 & 34.292 & 29.328 \\
\hline 2011 & 9.9971 & 7.444 & -16.39 & 0.8193 & 5.2741 \\
\hline 2012 & -3.315 & -3.41 & 72.43 & -1.35 & -4.907 \\
\hline 2013 & 2.4126 & -3.03 & 5.5838 & 5.0018 & 1.9197 \\
\hline 2014 & 8.1936 & -6.64 & 6.9884 & 0.7762 & 4.0742 \\
\hline 2015 & -8.947 & -12.1 & 12.332 & -5.335 & -4.453 \\
\hline 2016 & -2.386 & -4.84 & -2.882 & -2.85 & 1.1539 \\
\hline 2017 & 17.618 & 3.909 & 12.423 & 8.0301 & 14.519 \\
\hline 2018 & 20.951 & 4.575 & 15.92 & 3.8862 & 2.941 \\
\hline 2019 & -1.371 & -3.54 & 5.5373 & -6.361 & -3.271 \\
\hline 2020 & 5.4153 & 8.121 & -8.488 & 9.3566 & 0.618 \\
\hline
\end{tabular}

Sources; Author's calculations by using ITC data

Table 1 highlights the export growth of ASEAN-5 countries of the product group 85 in the world market. A positive and negative trend of growth of the selected product was seen in the analysis during 2003-2020.

Theoretically, the concept of competitiveness cannot be separated from international trade theories. According to Adam Smith (Smith, 1776), countries trade with each other depends on their absolute advantages-countries produce a product in which they have an absolute advantage and will exchange it for commodities in which they do not possess such advantage. In other words, countries export goods for which they use fewer inputs in production, and import goods that others can produce using fewer inputs, reflecting absolute differences in labor productivity. This idea was developed by Ricardo (Ricardo, 1817), arguing that not absolute but comparative advantages are responsible for global trade between nations. In the Ricardian model, production technology differences are the basis of $\mathrm{CA}$ and therefore production and trade are driven by the most effective use of resources. According to Ricardo (Ricardo, 1817), the economies should specialize in those commodities where they have a CA in, though technological superiority (high labor productivity) does not guarantee competitiveness.

Many studies have employed revealed comparative advantage index to evaluate the comparative 


\section{Review of Economics and Development Studies, Vol. 7 (2) 2021, 267-276}

advantage and competitiveness of the exports of different sectors of the world. Balassa and Marcus (1989) also utilized RCA index to examine the competitiveness of USA and Japan during 1967-1983. Amir (2000) measured the export competitiveness between Malaysia and other ASEAN economies by using the RCA index during 1994-1998. The results of this study illustrate that Malaysia reassessed the determinants which influenced its export competitiveness. The export competitiveness of China and ASEAN-5 countries in the USA and Japan was examined by Aziz and Bakar (2005) by employing conventional shift-share analysis during 1992-2003. The findings of the study indicated that China had strong positive net shifts in textile and clothing products in both markets. The Revealed comparative advantage was measured by Abidin and Loke (2008) for Malaysian manufacturing exports from 19962006, and the study concluded that Malaysia had a comparative advantage in electrical and electronics exports. The export competitiveness of electrical and electronic products of Malaysia was examined by Yaacob and Muhammad (2008) by employing RCA index and CMSA. The study measured the export competitiveness between Malaysia and other concerned competitor countries. The findings of the study illustrate that Malaysia had a strong CA in the selected commodities in the US market. The findings of CMSA illustrate that in the first sub-period, Malaysia was competitive in the selected four markets. However, in the second and third sub-period, CMSA results highlight that these selected exports increased due to structural effect.

Yahya et al., (2011) measured the export competitiveness of Malaysian products in the Arab gulf market by employing RCA index during 1998-2007. The tea competitiveness was measured by Oktaviana et al., (2016) by employing constant market share analysis in ASEAN economies during 20112014. The findings of the analysis illustrate that the major weakness of tea exports in Singapore, Thailand, Malaysia and Vietnam was the effect of market distribution. The determinants of export competitiveness were examined by Amanbayev and Masih (2017) by using time series data. The study concluded that inflation, interest rate, money supply and exchange rate were the major factors of export competitiveness of Malaysia. Yakob and Zam (2017) investigated the comparative advantage of the manufacturing export sector of Malaysia by utilizing several indices of RCA. This study measured RCA indices of 144 industries during the time span from 2010-2015. The findings of the analysis illustrate that high technology products had a high comparative advantage in the world market.

Shuquan (2019) used shift share analysis technique to compute net gain and losses for the ASEAN-5 and China from 1993 to 2007. During the first period (1993-1997), all selected five economies observed positive export growth. However, China and Philippines were champions in terms of net shift with positive value. During the second period (1998-2002), all ASEAN countries except China showed the negative net shift value, and the similar trends for third period (2003-2007) was observed also. The export competitiveness of leather exports of Pakistan was measured by Maqbool et al., (2019 a, b) by employing CMSA during 2003-2014. The results of the analysis indicate that Pakistan was competitive in the leather sector. The competitiveness of top five cotton exporting economies was measured by Maqbool et al., (2020) by using RCA indices The findings of the study depicts that Pakistan, India, China and USA had a comparative advantage, whereas Vietnam had a comparative advantage during 20082017 and comparative disadvantage from 2003-2007. Maqbool et al., (2020) examined the trade competitiveness of Pakistan's cereal products in the global market by using several indices from 20032018. The results illustrate that Pakistan was competitive in the concerned sector during the selected time span.

The present study measured comparative advantage and competitiveness of product group 85 (Electrical machinery and equipment and parts thereof; television image and sound recorders and reproducers, sound recorders and reproducers, and parts and accessories of such articles) of ASEAN-5 


\section{Review of Economics and Development Studies, Vol. 7 (2) 2021, 267-276}

economies. There is no valuable study available in the literature that has employed these four indices to measure the competitiveness of product group 85 of the selected economies. This present study will be beneficial and helpful for the policy makers of the economy to formulate their policies to boost economic position of the economy in the world market.

\section{Methods and material}

The present study focuses on the analysis of the competitiveness of the product group 85 of ASEAN-5 economies with an objective to measure the comparative advantage of its exports and to point out the position of this sector in the global market. The concept of comparative advantage is set by Balassa (1965) and the original model is explained as follows ( Balassa, 1965);

$$
\mathrm{RCA}=\frac{\mathrm{E}_{\mathrm{i}}^{\mathrm{t}} / \sum \mathrm{E}_{\mathrm{i}}^{\mathrm{t}}}{\mathrm{E}_{\mathrm{i}}^{\mathrm{W}} / \sum \mathrm{E}_{\mathrm{i}}^{\mathrm{w}}} \quad \text { (Source: Erkan and Kazim, 2014) }
$$

$\mathrm{E}_{\mathrm{i}}^{\mathrm{t}}=\quad$ Electrical machinery exports of the economy

$\sum E_{\mathrm{i}}^{\mathrm{t}}=$ Country's total exports

$\mathrm{E}_{\mathrm{i}}^{\mathrm{W}}=$ Global Electrical machinery exports

$\sum \mathrm{E}_{\mathrm{i}}^{\mathrm{W}}=$ Total exports of the world

The value of RCA index greater than 1 indicates CA, or in the terminology of Balassa, a revealed comparative advantage (Rivlin, 2000). The current study employs logarithms to the RCA index and LnRCA $>0$ indicates CA, while LnRCA $<0$ highlights the comparative disadvantage of the economy (Faustino, 2008).To contain the problem of skewness, the index of revealed symmetric comparative advantage has been employed. The RSCA index is defined as

$$
\mathrm{RSCA}=\frac{\mathrm{RCA}-1}{\mathrm{RCA}+1} \quad \text { (Source: Akhtar et al., } 2009 \text { and Ignjatijevic et al., 2013) }
$$

Vollrath (1991) commenced the index for comparative advantage, and this index is considered a good measure of measuring competitiveness because this index eliminates the dilemma of doublecounting in global market (Gnidchenko and Salnikov, 2015).

The Vollrath index is explained as

Where

$$
\text { RCA\# }=\frac{\left\{\frac{F_{i j}}{\left(\Sigma_{i} F_{i j}\right)-F_{i j}}\right\}}{\left\{\frac{\left(\Sigma_{j} F_{i j}\right)-F_{i j}}{\left(\left(\Sigma_{j} \Sigma_{i} F_{i j}\right)-\left(\Sigma_{j} F_{i j}\right)\right]-\left[\left(\Sigma_{i} F_{i j}\right)-F_{i j}\right.}\right\}}(\text { Source: Topcu and Sarigul, 2015) }
$$

$\mathrm{F}_{\mathrm{ij}}=$ Country's Electrical machinery exports

$\sum_{\mathrm{i}} \mathrm{F}_{\mathrm{ij}}=$ Country's total exports

$\sum_{\mathrm{j}} \mathrm{F}_{\mathrm{ij}}=$ World's Electrical machinery exports

$\sum_{\mathrm{j}} \sum_{\mathrm{i}} \mathrm{F}_{\mathrm{ij}}=$ World's total exports 
Review of Economics and Development Studies, Vol. 7 (2) 2021, 267-276

Table 2: RCA Classifications

\begin{tabular}{|c|c|c|}
\hline Sr. No & Classificationso of RCA & Interpretations \\
\hline A & $0<R C A \leq 1$ & Indicates no CA \\
\hline B & $1<\mathrm{RCA} \leq 2$ & Shows weak CA \\
\hline C & $2<\mathrm{RCA} \leq 4$ & Depicts moderate CA \\
\hline D & RCA $>4$ & Highlights strong CA \\
\hline
\end{tabular}

(Source; Hinloopen, 2001)

\section{Results and discussions}

Table 3 (a): Various Revealed Comparative Advantage Indices Related to the Electrical machinery exports of ASEAN economies 2003-2020

\begin{tabular}{|r|r|r|r|r|r|r|r|r|r|r|r|r|r|}
\hline & \multicolumn{4}{|c|}{ MALAYSIA } & \multicolumn{4}{|c|}{ PHILIPPINES } & \multicolumn{3}{c|}{ INDONESIA } \\
\hline Years & RCA & RSCA & LNRCA & RCA\# & RCA & RSCA & LNRCA & RCA\# & RCA & \multicolumn{1}{l|}{ RSCA } & LNRCA & RCA\# \\
\hline 2003 & 2.767 & 0.469 & 1.018 & 3.951 & 3.725 & 0.577 & 1.315 & 6.633 & 0.736 & -0.152 & -0.307 & 0.705 \\
\hline 2004 & 2.535 & 0.434 & 0.93 & 3.443 & 3.717 & 0.576 & 1.313 & 6.656 & 0.667 & -0.2 & -0.405 & 0.631 \\
\hline 2005 & 2.518 & 0.431 & 0.923 & 3.383 & 3.617 & 0.567 & 1.286 & 6.195 & 0.633 & -0.225 & -0.457 & 0.596 \\
\hline 2006 & 2.277 & 0.39 & 0.823 & 2.912 & 3.426 & 0.548 & 1.231 & 5.623 & 0.529 & -0.308 & -0.636 & 0.49 \\
\hline 2007 & 2.237 & 0.382 & 0.805 & 2.801 & 3.35 & 0.54 & 1.209 & 5.24 & 0.508 & -0.326 & -0.677 & 0.471 \\
\hline 2008 & 2.125 & 0.36 & 0.754 & 2.553 & 3.515 & 0.557 & 1.257 & 5.411 & 0.5 & -0.333 & -0.692 & 0.466 \\
\hline 2009 & 2.208 & 0.377 & 0.792 & 2.745 & 3.107 & 0.513 & 1.134 & 4.573 & 0.537 & -0.301 & -0.621 & 0.5 \\
\hline 2010 & 2.157 & 0.367 & 0.769 & 2.656 & 2.12 & 0.359 & 0.751 & 2.557 & 0.506 & -0.328 & -0.682 & 0.468 \\
\hline 2011 & 2.299 & 0.394 & 0.832 & 2.833 & 2.102 & 0.355 & 0.743 & 2.472 & 0.466 & -0.364 & -0.764 & 0.432 \\
\hline 2012 & 2.217 & 0.378 & 0.796 & 2.693 & 3.346 & 0.54 & 1.208 & 4.907 & 0.482 & -0.35 & -0.731 & 0.448 \\
\hline 2013 & 2.202 & 0.375 & 0.789 & 2.682 & 3.154 & 0.519 & 1.149 & 4.514 & 0.473 & -0.358 & -0.748 & 0.439 \\
\hline 2014 & 2.252 & 0.385 & 0.812 & 2.79 & 3.001 & 0.5 & 1.099 & 4.228 & 0.444 & -0.385 & -0.812 & 0.409 \\
\hline 2015 & 2.12 & 0.359 & 0.752 & 2.638 & 3.152 & 0.518 & 1.148 & 4.908 & 0.406 & -0.423 & -0.903 & 0.367 \\
\hline 2016 & 2.142 & 0.364 & 0.762 & 2.693 & 3.119 & 0.514 & 1.137 & 4.881 & 0.393 & -0.436 & -0.935 & 0.354 \\
\hline 2017 & 2.192 & 0.373 & 0.785 & 2.79 & 3.115 & 0.514 & 1.136 & 4.878 & 0.348 & -0.483 & -1.055 & 0.312 \\
\hline 2018 & 2.359 & 0.405 & 0.858 & 3.109 & 3.422 & 0.548 & 1.23 & 5.779 & 0.345 & -0.487 & -1.064 & 0.309 \\
\hline 2019 & 2.383 & 0.409 & 0.869 & 3.175 & 3.416 & 0.547 & 1.228 & 5.83 & 0.372 & -0.458 & -0.988 & 0.334 \\
\hline 2020 & 2.295 & 0.393 & 0.831 & 3.12 & 3.083 & 0.51 & 1.126 & 5.188 & 0.351 & -0.481 & -1.048 & 0.31 \\
\hline
\end{tabular}

Sources; Author's calculations by using ITC data 
Review of Economics and Development Studies, Vol. 7 (2) 2021, 267-276

Table 3 (b): Various Revealed Comparative Advantage Indices Related to the Electrical machinery exports of ASEAN economies 2003-2020

\begin{tabular}{|c|c|c|c|c|c|c|c|c|}
\hline & \multicolumn{4}{|c|}{ SINGAPORE } & \multicolumn{4}{|c|}{ THAILAND } \\
\hline Years & RCA & RSCA & LNRCA & RCA\# & RCA & RSCA & LNRCA & RCA\# \\
\hline 2003 & 2.771 & 0.47 & 1.019 & 4.024 & 1.566 & 0.221 & 0.449 & 1.732 \\
\hline 2004 & 2.832 & 0.478 & 1.041 & 4.2 & 1.526 & 0.208 & 0.423 & 1.677 \\
\hline 2005 & 2.78 & 0.471 & 1.022 & 4.04 & 1.389 & 0.163 & 0.329 & 1.486 \\
\hline 2006 & 2.806 & 0.475 & 1.032 & 4.13 & 1.303 & 0.132 & 0.265 & 1.375 \\
\hline 2007 & 2.754 & 0.467 & 1.013 & 3.92 & 1.282 & 0.124 & 0.248 & 1.344 \\
\hline 2008 & 2.65 & 0.452 & 0.975 & $3 \cdot 571$ & 1.202 & 0.092 & 0.184 & 1.24 \\
\hline 2009 & 2.504 & 0.429 & 0.918 & $3 \cdot 361$ & 1.127 & 0.06 & 0.12 & 1.151 \\
\hline 2010 & 2.583 & 0.442 & 0.949 & 3.537 & 1.14 & 0.065 & 0.131 & 1.166 \\
\hline 2011 & 2.444 & 0.419 & 0.894 & 3.147 & 1.133 & 0.062 & 0.125 & 1.155 \\
\hline 2012 & 2.414 & 0.414 & 0.881 & 3.088 & 1.073 & 0.035 & 0.07 & 1.085 \\
\hline 2013 & 2.442 & 0.419 & 0.893 & 3.163 & 1.069 & 0.033 & 0.067 & 1.081 \\
\hline 2014 & 2.411 & 0.414 & 0.88 & 3.131 & 1.083 & 0.04 & 0.08 & 1.098 \\
\hline 2015 & 2.428 & 0.416 & 0.887 & 3.283 & 0.99 & -0.01 & -0.01 & 0.988 \\
\hline 2016 & 2.424 & 0.416 & 0.885 & $3 \cdot 3$ & 0.968 & -0.02 & -0.03 & 0.963 \\
\hline 2017 & 2.31 & 0.396 & 0.837 & 3.064 & 1.002 & 9E-O4 & 0.002 & 1.002 \\
\hline 2018 & 2.197 & 0.374 & 0.787 & 2.828 & 0.984 & -0.01 & -0.02 & 0.981 \\
\hline 2019 & 2.141 & 0.363 & 0.761 & 2.729 & 0.956 & -0.02 & -0.05 & 0.948 \\
\hline 2020 & 2.189 & 0.373 & 0.784 & 2.929 & 0.922 & -0.04 & -0.08 & 0.907 \\
\hline
\end{tabular}

Sources; Author's calculations by using ITC data 
Figure 1: Revealed comparative advantage index of ASEAN-5 economies from 2003-2020

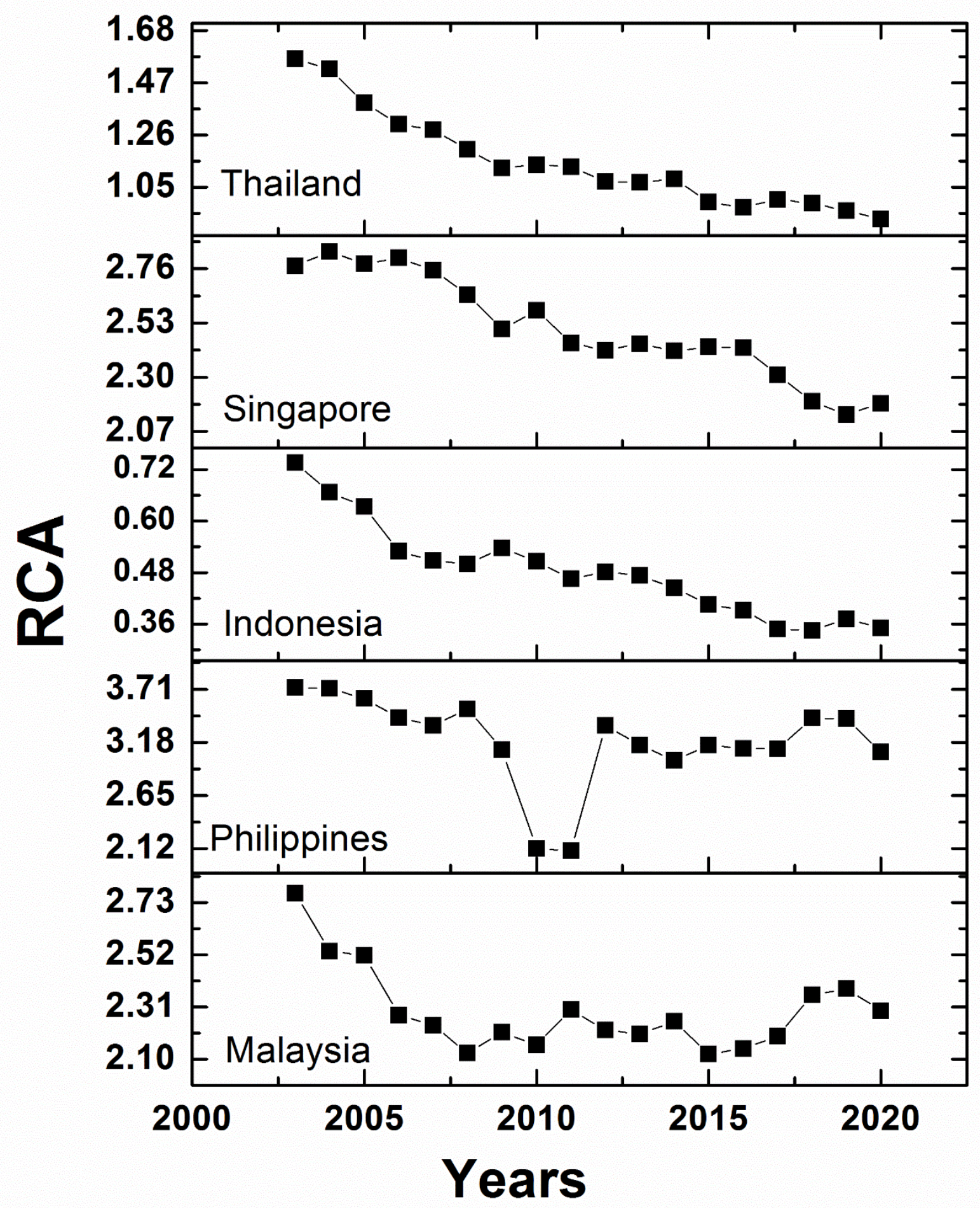

The aim of the current study is to examine export performance and competitiveness in the electrical machinery exports in the ASEAN- 5 economies by employing RCA, RSCA, LnRCA and Vollrath index from 2003-2020. Figure 1 depicts the trend of RCA index of ASEAN-5 countries in the selected export sector during 2003-2020. In table 3 (a,b), the findings of present study illustrate that Malaysia 


\section{Review of Economics and Development Studies, Vol. 7 (2) 2021, 267-276}

had a moderate CA in the electrical machinery exports having the values of RCA> 1during 2003-2020. The positive trend of LnRCA and RSCA depicts that Malaysia paid much attention on the specialization in the concerned sector and the positive values of these indices indicate comparative advantage. Moreover, the competitive advantage was observed by utilizing Vollrath index and the results show that Malaysia had a competitive advantage during the selected time period (Mohammad, 2020).

The RCA index of Philippines highlights that Philippines had a moderate comparative advantage from 2003-2020. The positive indices of RSCA and LnRCA indicate that Philippines had CA in the concerned export sector. In addition, the competitive advantage was also seen in this sector during 2003-2020. Philippines had a higher RCA index among the other selected economies in the global market in electrical machinery exports (Aldaba, 2020). Similarly, Singapore had a comparative and competitive advantage in this product group exports having the RCA values greater than 1 from 20032020. The indices of RSCA and LnRCA also highlights the comparative advantage in Singapore during the selected time span (Jayawickrama \& Thangavelu, 2010).

In Indonesia, the RCA index describes that Indonesia had a comparative disadvantage in the current export sector from 2003-2020 because the RCA index is less than 1 . The negative indices of RSCA and LnRCA highlight that Indonesia had a comparative disadvantage in this sector during above mentioned time period. The competitive disadvantage was also seen by Vollrath index during 20032020 in the selected product group in the world market (Tampubolon, 2020).

In Thailand, the results of RCA, RSCA, LnRCA and RCA\# indices depict that Thailand had a comparative and competitive advantage in the years from 2003-2014 and in the year 2017, while it had a comparative and competitive disadvantage in the remaining years (Apaitan et al., 2020).

\section{Conclusion}

This study aims to to measure the comparative advantage and competitiveness in the electric machinery in the selected ASEAN-5 economies by employing a set of revealed comparative advantage indices. The data has been collected from the International trade center (ITC) on the exports of electrical machinery of these economies during 2003-2020. The results of the study describe that Malaysia, Thailand, Singapore, Philippines had a comparative and competitive advantage in the selected product, whereas Indonesia had a comparative and competitive disadvantage. Only trade liberalization is not sufficient to enhance the market share of these countries' exports in the global market, some other structural factors such as research and development, productivity and technology are also needed to be addressed. The formation of the productive polices are direly needed to boost human capital formation and to increase technology transfer and innovation so that ASEAN-5 economies can improve their comparative and competitive advantage.

\section{References}

Abidin, M. Z., \& Loke, W. H. (2008). Revealed comparative advantage of Malaysian exports: The case for changing export composition. Asian Economic Papers, 7(3), 130-147.

Amanbayev, Y., \& Masih, M. (2017). What factors affect the export competitiveness? Malaysian evidence.

Aldaba, R. M. (2020). Trade reforms, competition, and innovation in the Philippines. In The Effects of Globalisation on Firm and Labour Performance (pp. 34-61). Routledge.

Apaitan, T., Banternghansa, C., Paweenawat, A., \& Samphantharak, K. (2020). Common Ownership, Domestic Competition, and Export: Evidence from Thailand (No. 140). Puey 
Review of Economics and Development Studies, Vol. 7 (2) 2021, 267-276

Ungphakorn Institute for Economic Research.

Akhtar, W., Sharif, M., \& Shah, H. (2009). Competitiveness of Pakistani fruits in the world market. The Lahore Journal of Economics, 14(2), 125.

Aziz, MIA., and NAA Bakr, (2005). The export competition between China and ASEAN-5 countries in the US and Japan; A survey on manufacturing sectors.

Balassa.B. (1965). Trade liberalization and "revealed" comparative advantage. The Manchester School, 33(2), 99-123.

Balassa, B., \& Noland, M. (1989). “'Revealed"Comparative Advantage in Japan and the United States. Journal of International Economic Integration, 8-22.

Bin Abu-Hussin, M. F., bin SUlAIMAN MOHAMAD, A. A., \& bin Mohd Hussin, M. Y. (2011). Capturing Arab gulf market: An analysis of Malaysian exports competitiveness in the market. African Journal of Business Management, 5(21), 8521-8535.

Erkan, B., \&Sarıçoban, K. (2014). Comparative Analysis of the Competitiveness in the Export of Science-Based Goods Regarding Turkey and the EU+13 Countries. International Journal of Business and Social Science, 5(8), 1.

Faustino, H. C. (2008). Intra-Industry Trade and Revealed Comparative Advantage: An Inverted-U Relationship. SOCIUS Working Paper. No:03. 7. 1-13

GHANI, G. M., \& SOFYAN, J. F. (2014). Trade Variety and Export Performance of ASEAN-5. Jurnal Ekonomi Malaysia, 48(1), 49-61.

Gnidchenko, A., \& Salnikov, V. (2015). Net comparative advantage index: Overcoming the drawbacks of the existing indices. Higher School of Economics Research Paper No. WP BRP, 119.

Hinloopen,j.(2001).On the empirical distribution of the Balassa index.Reviewed of world economics .137(1).13 1-49

He, S. (2019). Competition among China and ASEAN-5 in the US Market: A New Extension to Shift-Share Analysis. SocioEconomic Challenges, Volume 3, Issue 4, 2019 ISSN (print) 2520-6621, ISSN (online) - 2520-6214

https://comtrade.un.org

http;//www.worldatlas.com

Jayawickrama, A., \& Thangavelu, S. M. (2010). Trade linkages between China, India and Singapore. Journal of Economic Studies.

Ignjatijević, S., Matijašević, J., \& Milojević, I. (2014). Revealed comparative advantages and competitiveness of the processed food sector for the Danube countries. Custos E Agronegocio on line, 10(3), 256-281.

Maqbool, M. S., \& Mahmood, T. (2020). A Comparative Analysis of Export Competitiveness of Top Five Cotton Exporting Countries. Pakistan Journal of Social Sciences (PJSS), 4O(1).

Maqbool, M. S., Anwar, S., \& Hafeez-Ur-Rehman, M. T. (2019). Competitiveness of the Pakistan in Leather Export before and after Financial Crises: A Constant-Market-Share Analysis. J Glob Econ, 7(333), 2.

Maqbool, S., Anwar, S., \& Mahmood, T. (2019). Competitiveness, Diversification and Pakistan's Export Performance of Leather and Leather Products; A Constant Market Share Analysis. European Online Journal of Natural and Social Sciences: Proceedings, 8(2 (s)), pp141.

Maqbool, M. S., Mahmood, T., Hussain, S., \& Ashraf, M. (2020). Analysis of Trade Competitiveness of Pakistan Cereal Products in Global Perspective. Review of Economics and Development Studies, 6(1), 97-106.

Mahmood, A. (2000). Export specialization and competitiveness of the Malaysian manufacturing: trends, challenges, and prospects. 
Mohammad, A. N. M. M. B. (2020). ECONOMIC GROWTH OF MALAYSIA. Политика, экономика и инновации, (3 (32)).

Muhammad, N. M. N., \& Yaacob, H. C. (2008). Export competitiveness of Malaysian electrical and electronic (E\&E) product: Comparative study of China, Indonesia and Thailand. International Journal of Business and management, 3(7), 65-75.

Ricardo, D. On the Principles of Political Economy and Taxation; John Murray: London, UK, 1817

Rivlin, P. (2000). Trade potential in the Middle East: some optimistic findings. Middle East Review of International Affairs (MERIA), 4(1), 56-66.

Smith, A. An Inquiry into the Nature and Causes of the Wealth of Nations; Methuen \& Co.: London, UK, 1776.

Tampubolon, J. (2020). Indonesian Export Performance and Competitiveness in the ASEAN-China FTA. Available at SSRN 3594970.

Topçu, B. A., \& SümerliSarıül, S. (2015). Comparative advantage and the products mapping of exporting sectors in Turkey. AkademikSosyalAraştırmalarDergisi, 3(18), 330-348.

Vollrath, T. L. (1991). A theoretical evaluation of alternative trade intensity measures of revealed comparative advantage. Weltwirtschaftliches Archiv,127(2), 265-280.

Zam, N., \& Yakob, N. A. (2017). The Comparative Advantage of Malaysia Manufactured Exports. Saudi Journal of Business and Management Studies, 2, 521-531. 